\title{
Cellular injuries of spray-dried Lactobacillus spp. isolated from kefir and their impact on probiotic properties
}

\author{
Marina A. Golowczyc ${ }^{\mathrm{a}}$, Joana Silva ${ }^{\mathrm{b}}$, Paula Teixeira ${ }^{\mathrm{b}}$, Graciela L. De Antoni ${ }^{\mathrm{a}, \mathrm{c}}$, Analía G. Abraham ${ }^{\mathrm{a}, \mathrm{d}, *}$ \\ a Centro de Investigación y Desarrollo en Criotecnología de Alimentos (CIDCA), UNLP-CONICET. 47 y 116 (1900) La Plata, Argentina \\ b $\mathrm{CBQF} /$ Escola Superior de Biotecnologia, Universidade Católica Portuguesa, R. Dr. António Bernardino de Almeida, 4200-072 Porto, Portugal \\ c Cátedra de Microbiología, Facultad de Ciencias Exactas, UNLP, Argentina \\ d Área bioquímica y control de alimentos, Facultad de Ciencias Exactas, UNLP, Calle 47 y 115, 1900-La Plata, Argentina
}

Keywords:

Lactobacillus spp.

Kefir

Spray drying

Probiotic properties

\begin{abstract}
A B S T R A C T
The injuries caused by spray drying (SD) of three potential probiotic lactobacilli isolated from kefir grains and the impact on some probiotic properties, were evaluated. Results demonstrated that Lactobacillus plantarum 83114 and $L$. kefir 8321 showed a slight reduction of viability ( 0.11 and $0.29 \log$ CFU/ml respectively) after SD process, and L. kefir 8348 was found to be more sensitive to the process with a reduction in viability of $0.70 \log \mathrm{CFU} / \mathrm{ml}$. Neither membrane damage, evaluated by increased sensitivity to $\mathrm{NaCl}$, lysozyme, bile salt and penicillin G, nor changes in acidifying activity in MRS and milk by lactobacilli were detected after SD. L. plantarum 83114 and L. kefir 8321 after SD did not lose their capacity to adhere to intestinal cells. Nevertheless, L. kefir 8348 showed a significant loss of adhesion capacity after SD. In addition, rehydrated spray-dried L. kefir 8321 retained the ability to protect against Salmonella invasion of intestinal cells. This effect was observed when L. kefir is co-incubated with Salmonella before invasion assay.

This work shows that the membrane integrity evaluated by indirect methods and some probiotic properties of lactobacilli isolated from kefir did not change significantly after SD, and these powders could be used in functional foods applications.
\end{abstract}

\section{Introduction}

Probiotic bacteria, mainly specific strains of lactobacilli and bifidobacteria, have been shown to have beneficial effects on immunomodulation and in the alleviation or prevention of diverse intestinal disorders (Servin and Coconnier, 2003; Shah, 2007). Probiotic bacteria are reported to prevent the adherence, establishment and invasion of specific enteropathogens (Servin, 2004). Many criteria have been suggested for the selection of probiotics, among them lack of pathogenicity, tolerance of gastrointestinal conditions (acid and bile), ability to adhere to the gastrointestinal mucosa, and competitive exclusion of pathogens can be mentioned (Ouwehand et al., 1999; Coconnier et al., 2000; Lievin-Le Moal et al., 2002; Servin and Coconnier, 2003).

A large variety of microorganisms with potential use as a probiotic have been isolated from kefir grains. These microorganisms produce organics acids, bacteriocins and have the ability to adhere to intestinal cells and antagonize intestinal pathogens (Yüksekdag et al., 2004;

\footnotetext{
* Corresponding author. Centro de Investigación y Desarrollo en Criotecnología de Alimentos (CIDCA), UNLP-CONICET. 47 y 116 (1900) La Plata, Argentina. Tel.: + 54221 4249287; fax: + 542214890741.

E-mail addresses: aga@biol.unlp.edu.ar, analiaabraham@yahoo.com.ar (A.G.Abraham).
}

Powell et al., 2007; Golowczyc et al., 2007, 2008). Several lactobacilli strains isolated from kefir grains in our laboratory, were proved to have some characteristics present in a probiotic microorganism, among them can be mentioned: L. kefir CIDCA 8321 which adheres to Caco- 2 cells and protects epithelial cells against Salmonella invasion in vitro when they are previously co-incubated (Golowczyc et al., 2007), L. kefir CIDCA 8348 that adheres strongly to Caco-2 cells (Golowczyc et al., 2007) and L. plantarum CIDCA 83114 inhibits Salmonella and Escherichia coli in vitro, is able to adhere to Caco-2 cells (Golowczyc et al., 2008) and antagonizes E. coli 0157:H7 on Hep-2 cells (Hugo et al., 2008).

The preservation of microorganisms by different drying methodologies has been used for decades. Nowadays, workers have been investigating the use of spray drying (SD) as a convenient method for producing large quantities of some bacterial probiotic cultures (Gardiner et al., 2000; Desmond et al., 2001; Silva et al., 2002; Corcoran et al., 2004; Golowczyc et al, 2010). The principal advantages of SD are that it is less expensive and faster for producing large quantities of dried cells, than other techniques used to preserve microorganisms (Teixeira et al. 1995a, 1995b; Gardiner et al., 2000; Silva et al., 2005). The main disadvantage is that this process results in exposing the microorganisms to high temperatures which can be detrimental to the integrity of the cell (Teixeira et al., 1995a, 1995b; Gardiner et al., 2000; Silva et al., 2002, 2005). This process may affect a 
large number of cellular components, including DNA, RNA, cytoplasmic membrane and cell wall (Santivarangkna et al., 2008). Since some probiotic properties are closely related to the structure of the bacterial surface, it is very important to evaluate the cellular damage after SD to determine whether these spray-dried microorganisms maintain their properties. Therefore, the objective of this paper is to study injuries caused by the SD process on selected Lactobacillus spp., isolated from kefir grains and their effect on probiotic properties.

\section{Materials and methods}

\subsection{Strains and growth conditions}

Lactobacillus plantarum CIDCA 83114, Lactobacillus kefir CIDCA 8321 and Lactobacillus kefir CIDCA 8348 were previously isolated from kefir grains and identified (Garrote et al., 2001). Stock cultures were stored in $120 \mathrm{~g} / \mathrm{l}$ non-fat milk solids at $-80^{\circ} \mathrm{C}$. Working cultures were cultivated in De Man, Rogosa, Sharpe broth (MRS, Difco, Detroit, USA) at $30{ }^{\circ} \mathrm{C}$ for $48 \mathrm{~h}$ under static conditions. To prepare the inoculum, strains were inoculated into MRS broth $(1 \% \mathrm{v} / \mathrm{v})$ and incubated at $30{ }^{\circ} \mathrm{C}$ for $24 \mathrm{~h}$ (L. plantarum) or $48 \mathrm{~h}$ (L. kefir) under static conditions. Cells were harvested by centrifugation at $7000 \times \mathrm{g}$ at $4{ }^{\circ} \mathrm{C}$ for $10 \mathrm{~min}$ and washed twice by centrifugation with sterile Ringer's solution.

Salmonella enterica serovar Enteritidis CIDCA 101 (Golowczyc et al., 2007) was used for invasion experiments. It was grown in nutrient broth (Biokar Diagnostics, Beauvais, France, ref no. BK003HA) for 18 h at $37^{\circ} \mathrm{C}$.

\subsection{Spray drying process}

The cell pellets obtained as described above were resuspended to the original volume in reconstituted skim milk powder $(11 \% \mathrm{w} / \mathrm{v}$, Oxoid, Hampshire, UK) at room temperature. Each sample was spray dried in a pilot scale apparatus (Niro Atomizer, Copenhagen, Denmark). Spray drying conditions were: outlet air temperature $70{ }^{\circ} \mathrm{C}$, inlet air temperature $160^{\circ} \mathrm{C}$ and atomizing air pressure $3 \mathrm{Bar}$. Powder was collected in a single cyclone separator.

\subsection{Enumeration of viable bacteria}

To calculate the survivors after spray drying, samples were rehydrated to the original volume with sterile Ringer's solution. Samples were homogenized for $1 \mathrm{~min}$ in a vortex mixer and maintained at room temperature for $30 \mathrm{~min}$ and then, serially diluted. Bacteria were enumerated on MRS agar by the drop count technique.

\subsection{Cell damage evaluation}

The sensitivity of microorganisms to $\mathrm{NaCl}$, lysozyme, bile salt and penicillin $\mathrm{G}$, before and after drying processes, was determined. To select the adequate concentrations for each agent, the minimum inhibitory concentration (MIC) for each selective agent was determinated, and sub-inhibitory concentration was used (lower than MIC). All chemical additives except $\mathrm{NaCl}$ were added to MRS molten agar after filter sterilization. Fresh and dried L. plantarum cultures were plated on MRS agar plates supplemented separately with: $5 \%(\mathrm{w} / \mathrm{v})$ $\mathrm{NaCl}$ (Merck), $10 \mathrm{mg} / \mathrm{ml}$ lysozyme (Sigma, St. Louis, MO, USA), $0.75 \mu \mathrm{g} / \mathrm{ml}$ penicillin G (Sigma) or $0.25 \%$ (w/v) bile salt (Sigma). Fresh and spray-dried $L$. kefir cultures were plated on MRS agar plates supplemented separately with: $2 \%(\mathrm{w} / \mathrm{v}) \mathrm{NaCl}, 1 \mathrm{mg} / \mathrm{ml}$ lysozyme, $0.125 \mu \mathrm{g} / \mathrm{ml}$ penicillin $\mathrm{G}$ or $0.12 \%$ ( $\mathrm{w} / \mathrm{v}$ ) bile salt. The plates were examined after 2-3 days of aerobic incubation and viable numbers were compared with numbers obtained on unsupplemented MRS plates (without these selective agents).

Kinetics of acidification of MRS and milk added with yeast extract $(1 \% \mathrm{w} / \mathrm{v})$ were performed with fresh and rehydrated spray-dried microorganism. One $\mathrm{ml}$ of fresh or rehydrated spray-dried microorganism were transferred to $49 \mathrm{ml}$ of MRS or milk previously equilibrated at $30^{\circ} \mathrm{C}$ (final concentration was approx. $2 \times 10^{6} \mathrm{CFU} / \mathrm{ml}$ ). At regular intervals, samples were taken and $\mathrm{pH}$ values were determined.

\subsection{Caco-2/TC-7 cell culture and adhesion assay}

Growth conditions of cells culture and adhesion assays were carried out according to Golowczyc et al. (2007). Briefly, a Caco-2/TC7 monolayer was incubated with $0.5 \mathrm{ml}$ of fresh or rehydrated spraydried lactobacilli suspension $\left(2 \times 10^{8} \mathrm{CFU} / \mathrm{ml}\right.$ of PBS) and $0.5 \mathrm{ml}$ of DMEM of adhesion (without antibiotics or supplements) for $1 \mathrm{~h}$ at $37{ }^{\circ} \mathrm{C}$ in a $5 \% \mathrm{CO}_{2}-95 \%$ air atmospheres. Then, the monolayer was washed and lysed (40-50 min) by adding sterile distilled water. To determine the number of viable lactobacilli adhered to Caco-2/TC-7 cells, appropriate dilutions in $0.1 \%(\mathrm{w} / \mathrm{v})$ tryptone (Biokar Diagnostics) were plated in MRS and colony counts after $48 \mathrm{~h}$ incubation, were performed. Experiments were performed in triplicate on three consecutive cell passages.

\subsection{Salmonella invasion assays}

The invasion assay was carried out according to Golowczyc et al. (2007). Briefly, Caco-2/TC-7 monolayers at post-confluence were washed twice with sterile PBS ( $\mathrm{pH} 7.2$ ) and then $0.5 \mathrm{ml}$ of Salmonella suspension $\left(2 \times 10^{8} \mathrm{CFU} / \mathrm{ml}\right.$ of PBS) and $0.5 \mathrm{ml}$ of DMEM were added to each well and incubated for $1 \mathrm{~h}$ at $37{ }^{\circ} \mathrm{C}$ in a $5 \% \mathrm{CO}_{2}-95 \%$ air atmosphere. Then, for counting only bacteria located inside Caco-2/ TC-7 cells, $0.5 \mathrm{ml}$ of gentamicin (Sigma, $100 \mu \mathrm{g} / \mathrm{ml} \mathrm{PBS}$ ) were added to each well and the monolayer was incubated for $1 \mathrm{~h}$ at $37^{\circ} \mathrm{C}$. After that, monolayer was washed twice, lysed by adding sterile distilled water and colony counts were performed on nutrient agar (Biokar Diagnostics, ref no. BK021HA).

To study the $L$. kefir protection against Salmonella invasion, fresh (washed twice with PBS) or rehydrated spray-dried L. kefir 8321 $\left(2 \times 10^{8} \mathrm{CFU} / \mathrm{ml}\right)$ and Salmonella $\left(2 \times 10^{8} \mathrm{CFU} / \mathrm{ml}\right)$ were mixed and coincubated in PBS ( $\mathrm{pH} \mathrm{7.2)}$ ) for $1 \mathrm{~h}$ at $37^{\circ} \mathrm{C}$. Then, $0.5 \mathrm{ml}$ of the mixture was added to Caco-2/TC-7 monolayers and Salmonella invasion was determined as explained above.

\subsection{Statistical analysis}

Results were expressed as means \pm standard deviation of at least two independent experiments. For statistical comparisons, analysis of variance (ANOVA) was performed using the statistical program InfoStat Software (Grupo InfoStat, FCA, Universidad Nacional de Córdoba, Argentina). The Student $t$ test was used for mean comparison of survival after SD as well as Caco-2/TC-7 adhesion and invasion assays. All differences were considered statistically significant at a $\mathrm{p}<0.05$.

\section{Results and discussion}

\subsection{Survival after spray drying}

Table 1 shows the ability of the three investigated lactobacilli to survive the spray drying process (column named "initial count"). No significant differences were obtained among the three samples in terms of survival. Under dehydration conditions used, L. plantarum 83114 and $L$. kefir 8321 showed very little reduction of viability (0.11 and $0.29 \log$ CFU/ml respectively) while L. kefir 8348 was found to be more sensitive to the process with a reduction in viability of $0.70 \log \mathrm{CFU} / \mathrm{ml}$. Previously, we demonstrated that the outlet air temperature of $70{ }^{\circ} \mathrm{C}$ was associated with the highest survival rate for microorganisms during drying and subsequent storage (Golowczyc et al., 2010). For this reason, in this work the microorganisms were dried at an outlet air temperature of $70{ }^{\circ} \mathrm{C}$, because 
Table 1

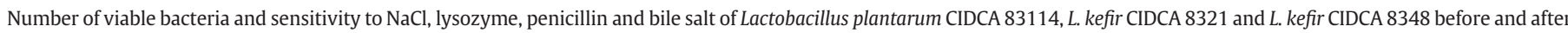
spray drying.

\begin{tabular}{|c|c|c|c|c|c|c|c|c|c|c|}
\hline \multirow[b]{3}{*}{ Strains } & \multicolumn{10}{|l|}{$\log \mathrm{CFU} / \mathrm{ml}$} \\
\hline & \multicolumn{2}{|l|}{ Initial count $^{\mathrm{a}}$} & \multicolumn{2}{|l|}{$\mathrm{NaCl}^{\mathrm{b}}$} & \multicolumn{2}{|l|}{ Lysozyme $^{\mathrm{b}}$} & \multicolumn{2}{|l|}{ Penicillin $^{\mathrm{b}}$} & \multicolumn{2}{|l|}{ Bile salt $^{\mathrm{b}}$} \\
\hline & Fresh & Dried & Fresh & Dried & Fresh & Dried & Fresh & Dried & Fresh & Dried \\
\hline L. plantarum CIDCA 83114 & $9.89 \pm 0.32$ & $9.78 \pm 0.17$ & $9.71 \pm 0.12$ & $9.77 \pm 0.10$ & $9.76 \pm 0.07$ & $9.86 \pm 0.19$ & $9.55 \pm 0.13$ & $9.60 \pm 0.18$ & $9.67 \pm 0.04$ & $9.57 \pm 0.12$ \\
\hline L. kefir CIDCA 8321 & $8.39 \pm 0.12$ & $8.10 \pm 0.08$ & $8.53 \pm 0.18$ & $8.31 \pm 0.09$ & $8.39 \pm 0.17$ & $8.25 \pm 0.22$ & $8.14 \pm 0.17$ & $8.30 \pm 0.11$ & $7.96 \pm 0.27$ & $7.84 \pm 0.20$ \\
\hline L. kefir CIDCA 8348 & $8.76 \pm 0.21$ & $8.16 \pm 0.13$ & $8.69 \pm 0.12$ & $8.17 \pm 0.10$ & $8.24 \pm 0.17$ & $8.31 \pm 0.12$ & $8.23 \pm 0.11$ & $8.10 \pm 0.06$ & $8.20 \pm 0.37$ & $7.92 \pm 0.18$ \\
\hline
\end{tabular}

a The values in the column represent the viable counts of strains before (fresh) and after (dried) SD on unsupplemented MRS (survival of strains).

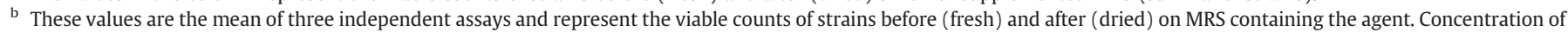
each agent for each strain is described in Materials and methods.

this allows the best result of energy savings. In the present work, the conditions of the dehydration process were slightly modified, specifically in product inlet pressure that was reduced from 5 to 3 bars and inlet air temperature was changed from $180^{\circ} \mathrm{C}$ to $160^{\circ} \mathrm{C}$. Under these conditions, the viability of the strains was improved and we obtained good results in survival during the drying process for $L$. plantarum 83114 and L. kefir 8321, while L. kefir 8348 was shown to be slightly more sensitive.

\subsection{Cellular injury after spray drying}

\subsubsection{Membrane damage}

It is known that during and after SD and also through subsequent storage in the dried state, cells can suffer from a variety of stresses including heat, osmotic and oxidative stress that result in the loss of cellular viability and activity (Teixeira et al., 1995a, 1995b; Gardiner et al., 2000; Silva et al., 2002, 2005, Golowczyc et al., 2010). After SD it is necessary to investigate whether viable bacteria maintain their properties and functionality, and these characteristics will be associated with membrane and cell wall integrity. Increased sensitivity of sub-lethally injured bacteria to $\mathrm{NaCl}$, lysozyme, penicillin and bile salt has been associated with cell membrane damage (Brennan et al., 1986; Teixeira et al., 1995b, 1997; Sunny-Roberts and Knorr, 2009). Sensitivity to different agents was studied as a measure of membrane damage (Table 1 ). No significant differences $(P>0.05)$ between the viable counts of the Lactobacillus strain on MRS containing each agent before and after SD was observed. Using these indirect approaches, we can infer that no cell damage was observed in spray-dried stationary phase cells. These results are in agreement to Corcoran et al. (2004). Gardiner et al. (2000) demonstrated that Lactobacillus paracasei was more resistant to drying than Lactobacillus salivarius and concluded that this is directly related with greater membrane damage in $L$. salivarius (evaluated by sensitivity to $\mathrm{NaCl}$ ). These results are similar to the results of Sunny-Roberts and Knorr (2009) on spraydried Lactobacillus rhamnosus GG (LGG) and L. rhamnosus E-97800 (E800). In contrast, in our case, taking into account that L. kefir 8348 was more sensitive to the drying process (showing $0.70 \mathrm{log}$ of viability reduction), the viable microorganisms that survive drying process have not demonstrated membrane damage under the conditions tested.

\subsubsection{Effect on metabolism}

The decrease of $\mathrm{pH}$ in MRS and milk following SD was determined and the results are shown in the Fig. 1. Acidification kinetics in both growth media by the activity of fresh (before SD) and dehydrated (after SD) L. plantarum 83114 did not show any significant difference $(\mathrm{P}>0.05)$. However, dehydrated $L$. kefir strains showed a delay in acidifying activity in MRS, however, the $\mathrm{pH}$ value reached at the end of fermentation time is similar. The same result was obtained by Teixeira et al. (1995a) with dehydrated L. delbrueckii subsp bulgaricus.

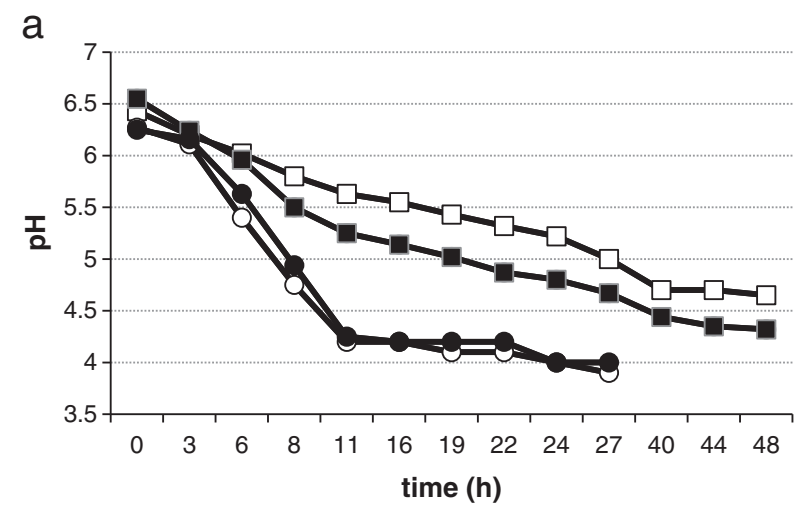

b

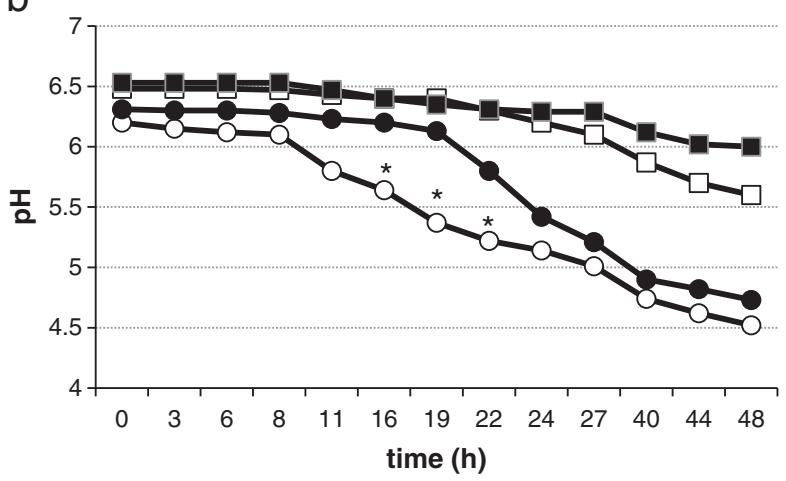

C

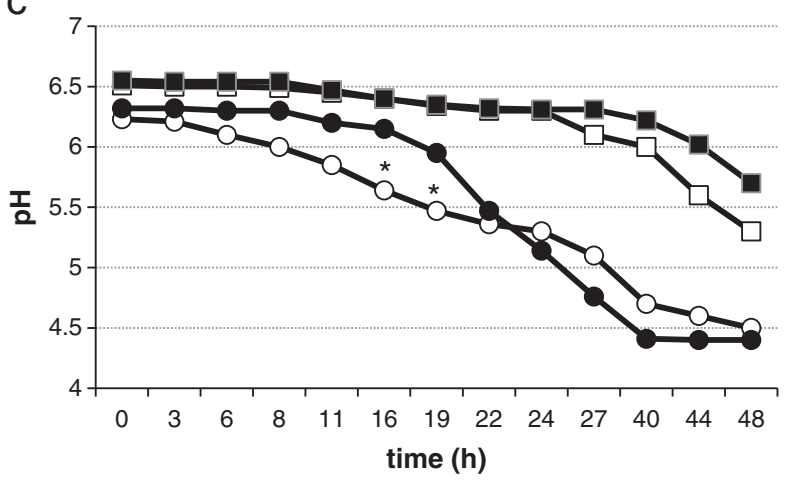

Fig. 1. Kinetics of acidification by fresh and dehydrated Lactobacillus plantarum CIDCA 83114 (a), L. kefir CIDCA 8348 (b) and L. kefir CIDCA 8321 (c) growing in MRS and milk with added $1 \%(\mathrm{w} / \mathrm{v})$ yeast extract. Dehydrated $(\square)$ and fresh $(\square)$ strain growing in milk, and dehydrated $(\bullet)$ and fresh $(O)$ strain growing in MRS. Each point represents the mean of three replicates. Points of $\mathrm{pH}$ at the same time of fermentation of kinetic performed with dehydrated and fresh bacteria that differs significantly are marked with *. 


\subsection{Effect of spray drying on the probiotic properties}

The ability to adhere to the intestinal epithelium and capacity to antagonize pathogenic bacteria has been suggested for the selection of probiotics (Tuomola and Salminen, 1998; Ouwehand et al., 2000). Adhesion is also considered important in immunomodulation, when only the adherent bacteria may have close contact with the immune function cells (Blum et al., 2002). The ability of fresh and dried Lactobacillus strains to adhere to Caco-2/TC-7 cells was assessed (Fig. 2). L. plantarum 83114 and L. kefir 8321 showed that after SD they did not lose their capacity to adhere to intestinal cells. However, $L$. kefir 8348 showed a significant loss of adhesion capacity after SD. This could be in agreement with the observed result that this strain is more sensitive to drying than the other strains tested, and although no damage was detected in the cell membrane, some surface structures used for adhesion may be injured.

Previously, we showed that L. kefir 8321 has the ability to coaggregate to Salmonella. This coaggregation lead to a protective effect on Caco-2/TC-7 cells against this pathogen by avoiding invasion (Golowczyc et al., 2007). Fig. 3 shows that rehydrated spray-dried $L$. kefir 8321 conferred less protection against Salmonella invasion compared to the fresh strain; however the capacity of spray-dried L. kefir 8321 to protect against Salmonella invasion was significantly different with respect to the control $(\mathrm{p}<0.05)$. This result indicated that after SD process, $L$. kefir 8321 strain still preserve the capacity to protect against the invasion of Salmonella. Since L. kefir 8321 carries surface layer (S-layer) proteins (Garrote et al., 2004) and these proteins are intimately associated with the antagonistic effect against Salmonella (Golowczyc et al., 2007), the decrease in protective effect may be due to partial structural changes of these proteins by heat. In addition, in a characterization study by DSC of the S-layer of these microorganisms, it was demonstrated that the S-layer has a structural transition at $70{ }^{\circ} \mathrm{C}$ (Mobili et al., 2009), the same temperature used to obtain the dehydrated strains.

\section{Conclusions}

The present results show that Lactobacillus strains assayed had good resistances to $\mathrm{SD}$, and the sensitivity to several agents that affect the cytoplasmic membrane/cell wall was not modified. However, it is very important the strain selection for development of a probiotic product that resist processing and maintains probiotic activity. In this sense, the two L. kefir strains evaluated in this work showed to be different in their resistance to SD and in adhesion capacity after the

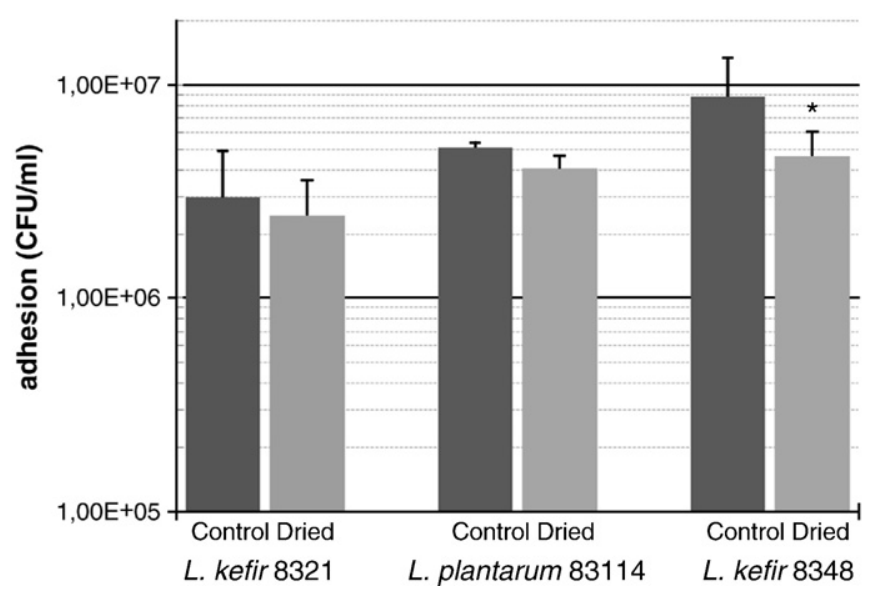

Fig. 2. Adhesion of fresh $(\square)$ and dried $(\square)$ Lactobacillus plantarum CIDCA 83114, L. kefir CIDCA 8348 and L. kefir CIDCA 8321 to Caco-2/TC-7 cells. * indicates significant differences with corresponding control at $\mathrm{p}<0.05$ by the Student $\mathrm{t}$ test.

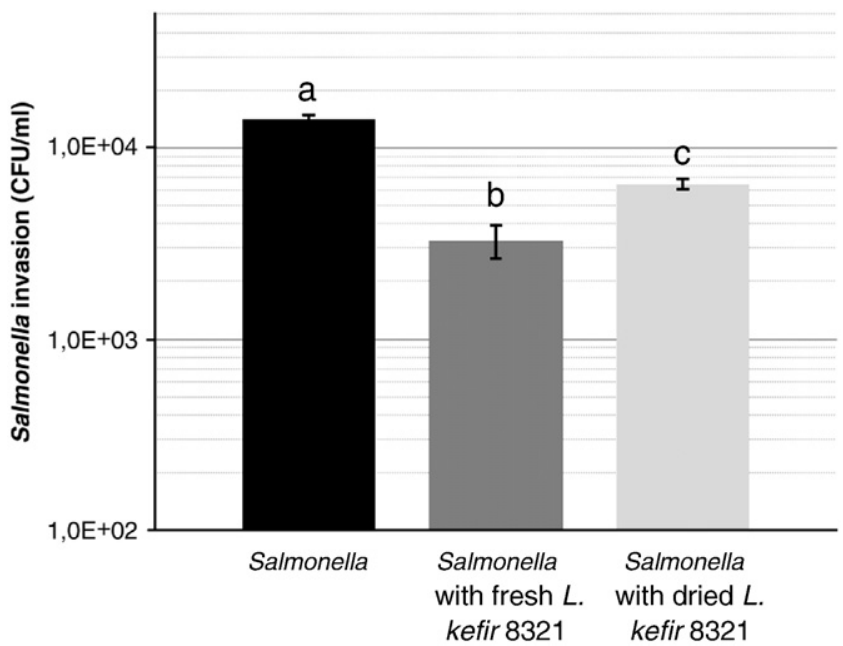

Fig. 3. Invasion of Salmonella into Caco-2/TC-7 cells co-incubated $\left(1 \mathrm{~h}, 37^{\circ} \mathrm{C}\right)$ with fresh $(\square)$ and dehydrated $(\square)$ Lactobacillus kefir CIDCA 8321. Salmonella incubated in PBS in the same conditions (without lactobacilli) was used as a control ( $\mathbf{\square})$. Different letters indicate significant differences at $\mathrm{p}<0.05$ by the Student $\mathrm{t}$ test.

process. In addition, although to a lesser extent compared to the fresh strain, it was demonstrated that rehydrated spray-dried L. kefir 8321 retained the ability to protect against Salmonella invasion when both microorganisms are previously co-incubated. This is the first report that evaluates the probiotic properties in vitro of lactobacilli isolated from kefir grains after SD, and based on results obtained in this work, these strains spray dried under the condition assayed could be used in the development of potential probiotic powders.

\section{Acknowledgements}

This work was supported by the Agencia Nacional de Investigaciones Científicas y Tecnológicas, CONICET, Facultad de Ciencias Exactas, UNLP, and Programa Iberoamericano de Ciencia y Tecnología para el Desarrollo (Cyted) Red Temática P107RT0207. Marina Golowczyc is a fellow of the Consejo Nacional de Investigaciones Científicas y Técnicas (CONICET). Analía G. Abraham is a member of the Carrera de Investigador Científico y Tecnológico of the CONICET. Graciela De Antoni is a researcher of the Comisión de Investigaciones Científicas de la Provincia de Buenos Aires (CIC-PBA).

\section{References}

Blum, S., Haller, D., Pfeifer, A., Schiffrin, E.J., 2002. Probiotics and immune response. Clinical Reviews in Allergy \& Immunology 22, 287-309.

Brennan, M., Wanismail, B., Johnson, M.C., Ray, B., 1986. Cellular damage in dried Lactobacillus acidophilus. Journal of Food Protection 49, 47-53.

Coconnier, M.H., Liévin, V., Lorrot, M., Servin, A., 2000. Anatagonistic activity of Lactobacillus acidophilus LB against intracellular Salmonella enterica serovar Typhimurium infecting human enterocyte-like Caco-2/TC-7 cells. Applied and Environmental Microbiology 66, 1152-1157.

Corcoran, B.M., Ross, R.P., Fitzgerald, G., Stanton, C., 2004. Comparative survival of probiotic lactobacilli spray dried in the presence of prebiotic substances. Journal of Applied Microbiology 96, 1024-1039.

Desmond, C., Stanton, C., Fitzgerald, G.F., Collins, K., Ross, R.P., 2001. Environmental adaptation of probiotic lactobacilli towards improvement of performance during spray drying. International Dairy Journal 11, 801-808.

Gardiner, G., O'Sullivan, E., Kelly, J., Auty, M.A.E., Fitzgerald, G.F., Collins, J.K., Ross, R.P., Stanton, C., 2000. Comparative survival of human-derived probiotic Lactobacillus paracasei and $L$. salivarius strains during heat treatment and spray drying. Applied and Environmental Microbiology 66, 2605-2612.

Garrote, G.L., Abraham, A.G., De Antoni, G.L., 2001. Chemical and microbiological characterization of kefir grains. The Journal of Dairy Research 68, 639-652.

Garrote, G.L., Delfederico, L., Bibiloni, R., Abraham, A.G., Pérez, P.F., Semorile, L., De Antoni, G.L., 2004. Lactobacilli isolated from kefir grains: Evidence of the presence of S-layer proteins. The Journal of Dairy Research 71, 222-230. 
Golowczyc, M.A., Mobili, P., Abraham, A.G., Garrote, G.L., De Antoni, G.L., 2007. Protective action of Lactobacillus kefir carrying S-layer against Salmonella enterica serovar Enteritidis. International Journal of Food Microbiology 118, 264-273.

Golowczyc, M., Gugliada, M., Hollman, A., Delfederico, L., Garrote, G.L., Abraham, A.G., Semorile, L., De Antoni, G.L., 2008. Characterization of homofermentative lactobacilli isolated from kefir grain: Potential use as probiotic. The Journal of Dairy Research 75, 211-217.

Golowczyc, M., Silva, J., Abraham, A., De Antoni, G., Teixeira, P., 2010. Preservation of probiotic strains isolated from kefir by spray drying. Letters in Applied Microbiology 50, 7-12.

Hugo, A.A., Kakisu, E., De Antoni, G.L., Pérez, P.F., 2008. Lactobacilli antagonize biological effects of enterohaemorrhagic Escherichia coli in vitro. Letters in Applied Microbiology 46, 613-619.

Lievin-Le Moal, V., Amsellem, R., Servin, A.L., Coconnier, M.H., 2002. Lactobacillus acidophilus (strain LB) from resident human adult gastrointestinal microflora exerts activity against brush border damage promoted by a diarrhoeagenic Escherichia coli in human enterocyte-like cells. Gut 50, 803-811.

Mobili, P., Londero, A., Maria, T.M.R., Eusébio, M.E.S., De Antoni, G.L., Fausto, R., GómezZavaglia, A., 2009. Characterization of S-layer proteins of Lactobacillus by FTIR spectroscopy and differential scanning calorimetry. Vibrational Spectroscopy 50 68-77.

Ouwehand, A.C., Kirjavainen, P.V., Grönlund, M.M., Isolauri, E., Salminen, S.J., 1999. Adhesion of probiotic micro-organisms to intestinal mucus. International Dairy Journal 9, 623-630.

Ouwehand, A.C., Isolauri, E., Kirjavainen, P.V., Tolkko, S., Salminen, S.J., 2000. The mucus binding of Bifidobacterium lactis Bb12 is enhanced in the presence of Lactobacillus GG and Lact. delbrueckii subsp. bulgaricus. Letters in Applied Microbiology 30, 10-13.

Powell, J.E., Witthuhn, R.C., Todorov, S.D., Dicks, L.M.T., 2007. Characterization of bacteriocin ST8KF produced by a kefir isolate Lactobacillus plantarum ST8KF. International Dairy Journal 17, 190-198.

Santivarangkna, C., Kulozik, U., Foerst, P., 2008. Inactivation mechanisms of lactic acid starter cultures preserved by drying processes. Journal of Applied Microbiology $105,1-13$.
Servin, A.L., 2004. Antagonistic activities of lactobacilli and bifidobacteria against microbial pathogens. FEMS Microbiology Reviews 28, 405-440.

Servin, A.L., Coconnier, M.H., 2003. Adhesion of probiotic strains to the intestina mucosa and the interaction with pathogens. Best Practice \& Research. Clinical Gastroenterology 17, 741-754.

Shah, N.P., 2007. Functional cultures and health benefits. International Dairy Journal 17, 1262-1277.

Silva, J., Carvalho, A.S., Teixeira, P., Gibbs, P.A., 2002. Bacteriocin production by spray dried lactic acid bacteria. Letters in Applied Microbiology 34, 77-81.

Silva, J., Carvalho, A.S., Vitorino, R., Ferreira, R., Domingues, P., Amado, F., Teixeira, P., Gibbs, P., 2005. Effect of the $\mathrm{pH}$ of growth on the survival of Lactobacillus delbruecki subsp. bulgaricus to stress conditions during spray drying. Journal of Applied Microbiology 98, 775-782.

Sunny-Roberts, E.O., Knorr, D., 2009. The protective effect of monosodium glutamate on survival of Lactobacillus rhamnosus GG and Lactobacillus rhamnosus E-97800 (E800) strains during spray-drying and storage in trehalose-containing powders. International Dairy Journal 19, 209-214.

Teixeira, P., Castro, H., Kirby, R., 1995a. Spray drying as a method for preparing concentrated cultures of Lactobacillus bulgaricus. The Journal of Applied Bacteriology $78,456-462$.

Teixeira, P.C., Castro, M.H., Malcata, F.X., Kirby, R.M., 1995b. Survival of Lactobacillus delbrueckii ssp. bulgaricus following spray drying. Journal of Dairy Science 78, 1025-1031.

Teixeira, P., Castro, H., Mohacsi-Farkas, C., Kirby, R., 1997. Identification of sites of injury in Lactobacillus bulgaricus during heat stress. Journal of Applied Microbiology 83, 219-226.

Tuomola, E.M., Salminen, S.J., 1998. Adhesion of some probiotic and dairy Lactobacillus strains to Caco-2 cell cultures. International Journal of Food Microbiology 41 45-51.

Yüksekdag, Z.N., Beyatli, Y., Aslim, B., 2004. Determination of some characteristics of coccoid forms of lactic acid bacteria isolated from Turkish kefirs with natural probiotic. Lebensmittel-Wissenschaft und Technologie 37, 663-667. 